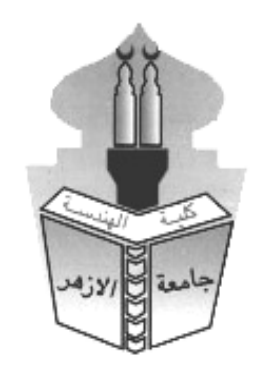

\title{
IMPROVING PERFORMANCE OF CONSTRUCTION PROJECTS BY INTEGARATING RISK INTO EARNED VALUE MANAGEMENT: ALITURATURE REVIEW
}

\author{
Alaa Elghandour*1, Ali Fathi Eid 2, Hazzem el daly3 \\ 1 Faculty of Engineering, Department of Architecture, Ain-Shames University, Cairo, Egypt. \\ 2 Professor, Department of Architecture, Faculty of Engineering, Ain-Shams University, Cairo, Egypt. \\ 3 Assistant Professor, Department of Architecture, Faculty of Engineering, Ain-Shams University, Cairo, Egypt. \\ *Corresponding Author E-mail: alaaelghandor@gmail.com
}

Received: 19 February 2021 Accepted: 04 May 2021

\begin{abstract}
The actual cost and time of the construction projects are different from the planned. Cost and time overruns are critical issues. Therefore, these overruns highlight the importance of the monitor and control phase for the project's success, So the project needs to monitor and control project elements as time, cost, and scope, in addition to risks, where construction projects face more risks. Earned value management $(E V M)$ is a technique for evaluating project performance, used for early tracking to indicate that the project on planned time and estimated cost or not. Risk is considered part of the EVM process. Earned Value Management and risk management (RM) are two popular techniques used to monitor and control project performance.

Therefore, the main objective of this paper to improve the performance of construction projects by integrating risk into Earned Value Management. Achieving this aim shall help the project managers to take corrective actions. In order to achieve the objective of this paper, present a literature review, where several chosen literature sources published during the last decade were analyzed and divided into five main categories: EVM, RM, Integration between EVM and Risk, Risk Contingency Reserve (CR), Schedule Reserve (SR), Software. The findings of this paper identified the value-added from applying integration and the guidelines for this process application. Therefore, it recommends integrating Earned Value Management into Risk from a cost and time perspective with the use of accurate software to improve construction project performance.
\end{abstract}

KEY WORDS: Earned Value Management, Performance of Construction projects, Risk Management, Integration.

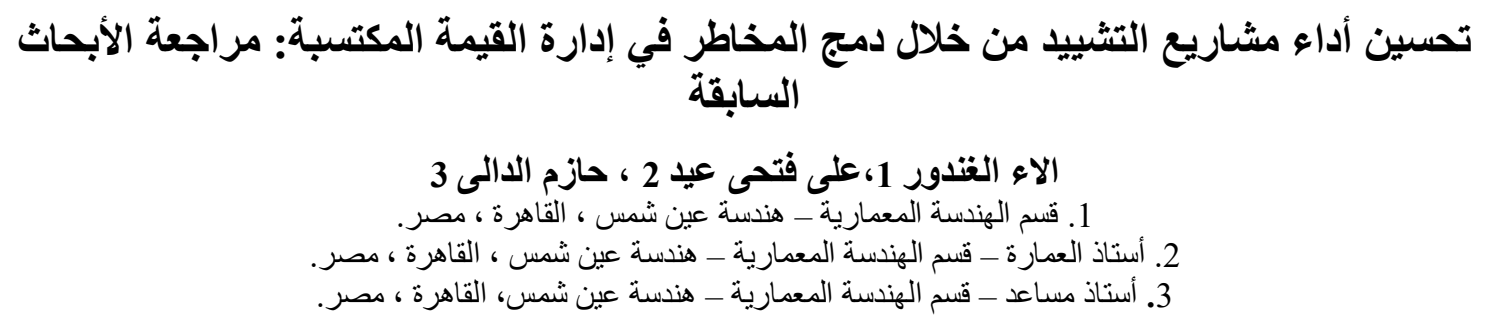

ملخص البحث

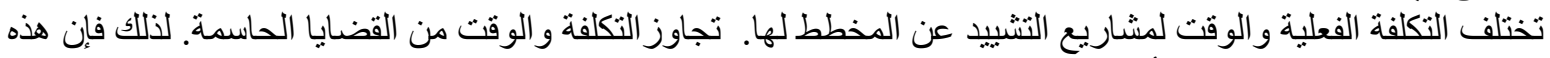

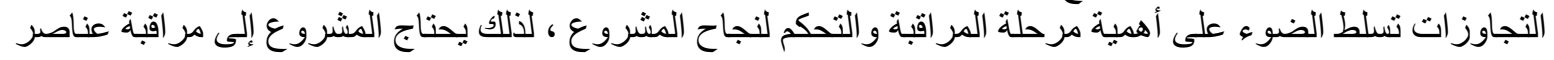




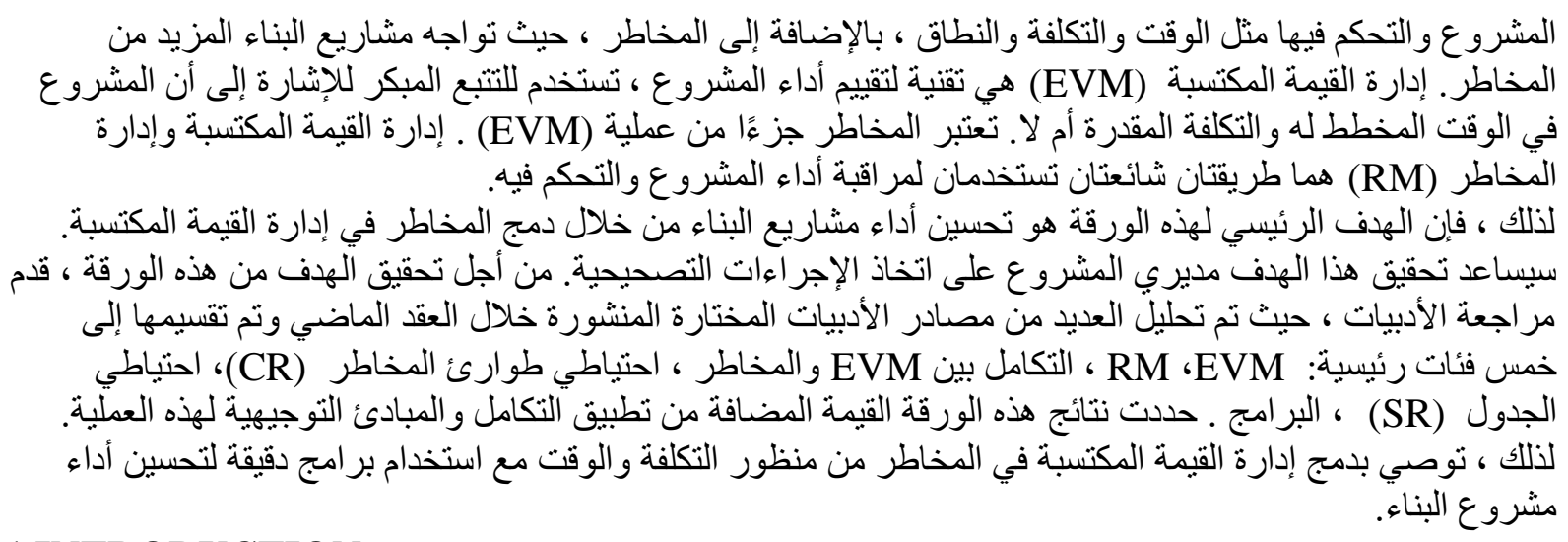

\section{INTRODUCTION}

The construction industry is considered one of the sources of economic growth, development, and economic activity. It has a role in the economic development of a country. Cost and time monitoring are essential factors for project success. The project management's main objective is to complete the project as per planned cost and time.

Keeping the project cost within the baseline cost and in time is the essential concern of the project stakeholders, from here discover the importance of the baseline cost and schedule controlling and can check if the project schedule is suitable and can perform according to available resources. So there is a need for a tool to monitor the time and cost plans. Earned value management is a popular control tool. The birthplace of EVM is the US Department of Defense (DOD). The DOD in the 1960s decided that it needed more appropriate controls to manage its projects and related budgets. More specifically, they intend to obtain early warning signals and predict the outcome of their projects early in the life cycle of the project. (Fleming, Koppelman, 1994).

EVM is one of the various technologies that control the project, and it can use effectively to monitor the actual cost of the project on a specific date. Besides, risk management can predict the future, whether it is a threat or an opportunity. An earned value management system only provides data inferred from past performance. Difficulty to use earned value management to predict the future. (Hillson D, 2004).

At first glance, it appears that there is no further connection between the two methods, but the basic principles of EVM are influenced by risk management and risk analysis. In PMBoK®, integration is implicit, not even called "incorporating between EVM and RM ". Each risk element should be clear in the EVM methodology. (PMI, 2013).

This paper focuses on the integration impact. Since the EVM depends on comparing the project execution value and the planned value, it introduces the components of risk or plan changes caused by RM. Therefore, the integration process makes EVM obtained with more monitoring functions.

\subsection{Problem}

Most construction projects are suffering from two kinds of problems, over cost and schedule delay around the world (Nawar S., 2017; Rosenfeld, 2014; Wanjari \& Dobariya, 2016; Marzouk et al., 2008; Sambasivan \& Soon, 2007; Assaf \& Al-Hejji 2006).

In most developing countries, the cost and time overrun in projects increase than others. Many studies had discussed the main reasons, which led to these unplanned results, some of these factors have high rank reported in previous studies, which are (Change of Scope- Poor financial control on-site- poor project planning and scheduling) (Aziz, R. F., 2013; Yahia et al., 2011; Khodeir L. 2015; Shibnai A., Salah K., 2015; Razek M. E.,2008). Therefore, these factors and others can be controlled and avoid its impact through monitoring and controlling the project, and get indicators about the cost and time of the project early which increase the probability of project success and avoid poor construction project performance. 


\subsection{Aim}

This paper aims to review the extent of interest in the construction field in using earned value and risk management to improve project performance to help project managers to take corrective action during the excavation phase.

\subsection{Methodology}

The paper relies on a literature review, in which it reviews and analyzes some researches during 1998-2019, and highlights areas of focus, gaps, and the potential for future researches. A literature review; firstly, discusses the earned value management concept, second discusses risk management concept, including risk contingencies final, it provides an understanding of EVM and RM as discrete disciplines as well as identifying, understanding the linkages between them, particularly in the excavation phase, and presents the software discussed in two different techniques as shown in Figure (1).

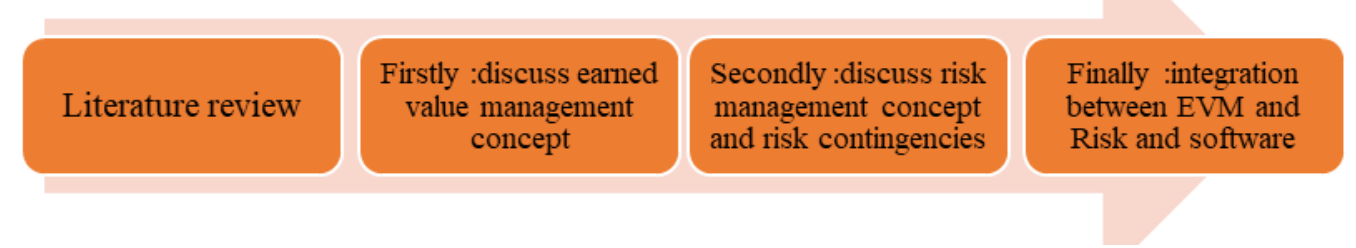

Figure (1) Research Methodology, Source: Authors

\section{Literature Review}

The literature sources discussed earned value as an effective tool for monitoring and controlling project performance. Other sources explained Earned Schedule as an extension of Earned Value Management equations used for time indicators. Several studies discussed the risk management process and analyses using the software. Few studies have emphasized the importance of assessing and managing risk contingencies reserve during the project excavation stage. It also presented sources published and books about the integration process between risk management and earned value. Therefore, the keywords in this paper were mainly covered by the previous researches, and divided into the following categories, as shown in Figure (2).

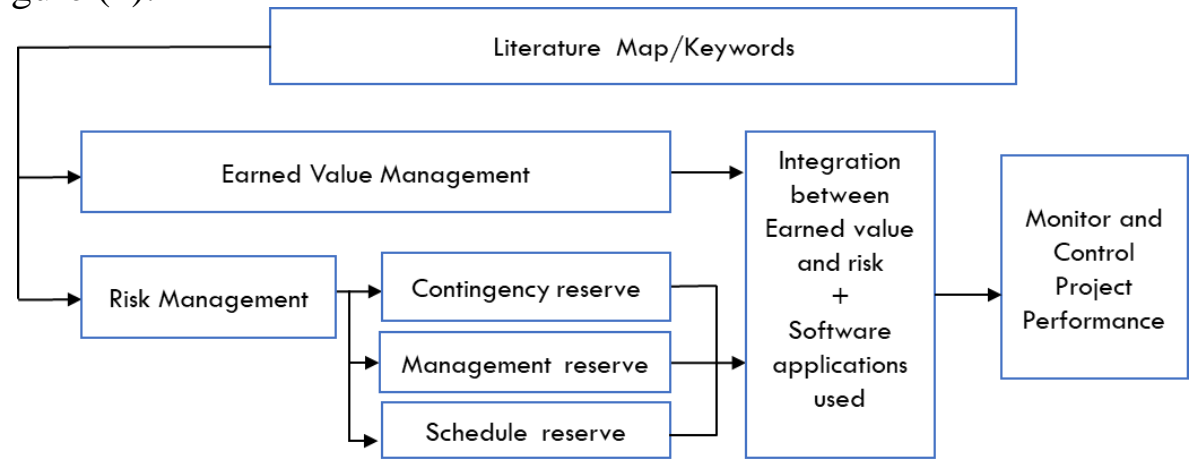

Figure (2).: Literature Review Main Categories. Source: Authors

This paper depends on some chosen previous researches published in the certain period as mentioned below, which have interest in some categories and classified them throughout the five main categories with their dates in order to have a clearer vision of the literature map and previous researches in the field of study and classified them into tables (1)\&(2)\&(3) as shown below Five Categories A. Earned Value Management (EVM), B. Risk Management (RM), C. Risk Contingency Reserve (CR), D. Integration Between Earned Value and Risk Management, Earned Value and Risk Software.

Firstly, category (A) Earned Value Management (28) researches divided into ( 21 research paper - 7 thesis ) from different countries as ( Turkey, India, Malaysia, Spain, the USA, United Kingdom, Belgium, Poland ), Category (B) Risk Management (10)researches divided into (9 research paper- 1 thesis ), from countries ( Poland, South Africa, Italy, Malaysia, Sweden, the 
USA, Egypt), Category (C) Risk Contingencies (6) researches (4 research paper, 2 theses), Category (D) Integration between EVM and Risk (19) divided into (18 research paper - 1 master thesis) form countries (Spain, Iran, Portugal, United Kingdom, India, the USA, Egypt), Category (E)Software (7 research paper) note, researches about earned value and risk include software too in its applications but traditional software as shown in part (2.3) presented software.

Table (1)-Category (A): earned value management. Publication of studies began in 1994, and the rate of studies in this direction is increasing until now. When the time is unclear, the researchers started to discuss time indicators and add new equations called earned schedules discussed recently.

Table (1) Literature Maps for Category (A) Earned Value Management, Source Authors

\begin{tabular}{|c|c|c|c|c|c|c|c|c|}
\hline \multicolumn{9}{|c|}{ Category } \\
\hline \multicolumn{9}{|c|}{ A. Earned Value Management (EVM) } \\
\hline No & Author & Date & No & Author & Date & No & Author & Date \\
\hline 1 & Nouban, F. et al. & 2020 & 10 & Hakkinen M. & 2015 & 20 & Kwak, Y.H., \& Anbari, F. T. & 2010 \\
\hline 2 & Nalawade S., et al. & 2019 & 11 & $\begin{array}{l}\text { Chin Keng, T.\& } \\
\text { Shahdan, N. } \\
\end{array}$ & 2015 & 21 & Khan, M. et al. & 2010 \\
\hline 3 & Eirgash,M. & 2019 & 12 & Abd El-Latif, E. & 2014 & 22 & Buyse \& Vandenbussche & 2010 \\
\hline 4 & $\begin{array}{l}\text { K. Araszkiewicz \& M. } \\
\text { Bochenek }\end{array}$ & 2019 & 13 & Czemplik,A. & 2014 & 23 & Czarnigowska Agata. & 2008 \\
\hline 5 & Mahdi, I., et al. & 2018 & 14 & De Marco \& Narbaev & 2013 & 24 & Douglas C. Bower & 2007 \\
\hline 6 & Dang, G & 2017 & 15 & Farag, M. & 2012 & 25 & Lipke \& Henderson & 2006 \\
\hline 7 & Mohamed, M. & 2016 & 16 & Anbari, F. T. & 2012 & 26 & Anbari, F.T. & 2003 \\
\hline 8 & Mahdi I.M.,et al. & 2016 & 17 & Lukas, J. A. & 2012 & 27 & Richard D. Hayes, III. & 2001 \\
\hline 9 & Shukla, M. & 2016 & 19 & $\begin{array}{l}\text { Pajares, J., López- } \\
\text { Paredes, A. }\end{array}$ & 2011 & 28 & Fleming, Koppelman & 1994 \\
\hline
\end{tabular}

Table (2)-Category (B): Risk Management and Risk Reserves. RM is not a new direction where the rate of studies in this direction is increasing to date. Recent studies have been added (2014-2019). However, the estimated risk contingency reserves, especially how to include it in the baseline to support the monitoring process. Recently selected studies about risk reserves from 2011 to 2018 illustrate the process and its application of contingency reserves. Risk management software has been used a lot in risk analysis studies.

Table (2) Literature Map for Categories (B) \&(C): RM \& Risk Contingencies, Source AuthorS

\begin{tabular}{|c|c|c|c|c|c|c|c|c|}
\hline \multicolumn{9}{|c|}{ Category } \\
\hline \multicolumn{6}{|c|}{ B. Risk Management (RM) } & \multicolumn{3}{|c|}{ C. Risk contingency } \\
\hline No & Author & Date & No & Author & Date & No & Author & Date \\
\hline 1 & Szymański P. & 2017 & 5 & Shrivastava, N. K. & 2014 & 1 & Oritiz I. & 2018 \\
\hline 2 & Nketekete M., et al & 2016 & 6 & Serpella A. etal. & 2014 & 2 & Hammad M. & 2018 \\
\hline 3 & Iqbal S. & 2015 & 7 & Eldosouky I., alet & 2014 & 3 & Nawar $S$. & 2017 \\
\hline 4 & Claudius A. Peleskei & 2015 & 8 & H. Al-Shibly & 2013 & 4 & Shrivastava, N. K. & 2014 \\
\hline 5 & Suchith Reddy & 2015 & 9 & Kim, S. D. & 2012 & 5 & England, K. \& Moreci, J. & 2012 \\
\hline 6 & Ismail, I. & 2014 & 10 & Gajweska E., Ropel M. & 2011 & 6 & Sheives, $\mathrm{T}$. & 2011 \\
\hline
\end{tabular}

Table (3)-Category (D\&E): Integration between earned value management and risk management and software. The concept of integration is not old, it only started as recently as 2004, so there have been limited studies published on how to implement and monitor the process. For software, especially the EVM method, some studies use professional software (primavera- Microsoft project). EVM and risk software were used separately, but there were few/limited in the integration process. 
IMPROVING PERFORMANCE OF CONSTRUCTION PROJECTS IN EGYPT BY INTEGARATING RISK INTO EARNED VALUE MANAGEMENT: ALITURATURE REVIEW

Table (3) Literature for Categories (D)\& (E)-Integration EVM \& Risk, Software, Source AuthorS

\begin{tabular}{|c|c|c|c|c|c|c|c|c|}
\hline \multicolumn{6}{|c|}{ D. Integration Between Earned Value \& Risk Management } & \multicolumn{3}{|c|}{ E. Software } \\
\hline No & Author & Date & No & Author & Date & No & Author & Date \\
\hline 1 & Bonato, F.al et & 2019 & 11 & Acebes F.al.et. & 2014 & \multirow{2}{*}{1} & \multirow{2}{*}{ S., Lavanya , Narayana, Dr. G } & \multirow{2}{*}{2019} \\
\hline 2 & Khesal, T & 2019 & 12 & Georgieva S. & 2014 & & & \\
\hline 3 & brahim, $\mathrm{M}$. & 2018 & 13 & Jonas, V. \& Bone, L & 2012 & \multirow{2}{*}{2} & \multirow{2}{*}{ Nalawade S., etal } & \multirow{2}{*}{2019} \\
\hline 4 & Tereso, A.,et al. & 2018 & 14 & Xiaozhong Yu\& Hong $\mathrm{Hu}$ & 2010 & & & \\
\hline 5 & El Mikawi, M., et al. & 2017 & 15 & Sheives, $\mathrm{T}$. & 2011 & \multirow{2}{*}{3} & \multirow{2}{*}{ Sagar, K., Vyas,G. } & \multirow{2}{*}{2012} \\
\hline 6 & Akhtar, T & 2017 & 16 & Hillson, D. & 2011 & & & \\
\hline 7 & Elwany M., ElsharkawyA. & 2016 & 17 & Shepherd, B. & 2008 & 4 & Subramanian T. et al. & 2014 \\
\hline 8 & $\begin{array}{l}\text { KhodaBandeh Lou, A. et } \\
\text { al. }\end{array}$ & 2016 & 18 & Nobuhiro \& Akihiro & 2008 & 5 & Masood S. et al. & 2014 \\
\hline 9 & $\begin{array}{l}\text { G. Pavan Kumar, SS. } \\
\text { Asadi. }\end{array}$ & 2016 & \multirow[t]{2}{*}{19} & \multirow{2}{*}{ Hillson, D. } & \multirow[t]{2}{*}{2004} & 6 & Jonas, $\mathrm{V}$. & 2013 \\
\hline 10 & Shah, Akhtar H. & 2014 & & & & 7 & Koster K. et al. & 2011 \\
\hline
\end{tabular}

Table (4) present a list of books and guides from (1998-2020), and it's divided according to categories with dates and arranged from the latest dates to the oldest dates.

Note: categories, where: General Project Management (PM General), Earned Schedule (ES), Work Breach Down Structure (WBS). There are different editions from some books as PMBOOK but not displayed all in this research.

Table (4) Books and Guide Related to Categories with Dates- (1998-2017), Source: Author

\begin{tabular}{|c|c|c|c|c|}
\hline No & Author/ Applicable agency & Date & Topic & Categories \\
\hline 1 & $\begin{array}{l}\text { Project Management Institute } \\
\text { (PMI) }\end{array}$ & 2017 & $\begin{array}{l}\text { A Guide to the Project Management Body of } \\
\text { Knowledge (PMBOK® GUIDE) 6th Edition }\end{array}$ & PM General \\
\hline 2 & $\begin{array}{l}\text { Department of Defense } \\
\text { (DOE) }\end{array}$ & 2016 & $\begin{array}{l}\text { The DOE Earned Value Management System } \\
\text { Interpretation Handbook EVMSIH (2.0) }\end{array}$ & EVM \\
\hline 3 & $\begin{array}{c}\text { Association for Project } \\
\text { Management (APM) }\end{array}$ & 2013 & Earned Value Management Handbook & EVM \\
\hline 4 & $\begin{array}{l}\text { Project Management Institute } \\
\text { (PMI) } \\
\end{array}$ & 2011 & $\begin{array}{l}\text { "Practice Standard for Earned Value } \\
\text { Management, Second Edition " }\end{array}$ & EVM \\
\hline 5 & Koster K. et al. & 2011 & Earned Value Management For Dummies ${ }^{\circledR}$ & EVM \\
\hline 6 & $\begin{array}{l}\text { Davis A. - Association for } \\
\text { Project Management (APM) }\end{array}$ & 2010 & $\begin{array}{c}\text { EARNED SCHEDULE, An emerging Earned } \\
\text { Value technique, APM }\end{array}$ & ES \\
\hline 7 & $\begin{array}{l}\text { Quentin W. Fleming \& Joel } \\
\text { M. Koppelman }\end{array}$ & 2010 & $\begin{array}{c}\text { Earned Value Project Management_-Fourth } \\
\text { Edition }\end{array}$ & EVM \\
\hline 8 & $\begin{array}{c}\text { United States Government } \\
\text { Accountability Office (GAO) }\end{array}$ & 2009 & $\begin{array}{c}\text { GAO Cost Estimating and Assessment Guide } \\
\text { (Best Practices for Developing and } \\
\text { Managing Capital Program Costs) } \\
\end{array}$ & $\begin{array}{l}\text { EVM \& Risk } \\
\text { \& Cost } \\
\text { Estimation }\end{array}$ \\
\hline 9 & $\begin{array}{l}\text { Project Management Institute } \\
\text { (PMI) } \\
\end{array}$ & 2009 & $\begin{array}{c}\text { Practice Strandered for Project Risk } \\
\text { Management } \\
\end{array}$ & $\begin{array}{c}\text { Risk } \\
\text { Management }\end{array}$ \\
\hline 10 & $\begin{array}{c}\text { Association for Project } \\
\text { Management (APM) }\end{array}$ & 2008 & $\begin{array}{c}\text { Interfacing Risk and Earned Value } \\
\text { Management }\end{array}$ & $\begin{array}{l}\text { Integration } \\
\text { EVM \& Risk }\end{array}$ \\
\hline 11 & $\begin{array}{c}\text { Association for Project } \\
\text { Management (APM) }\end{array}$ & 2008 B & $\begin{array}{c}\text { Earned Value Management: APM } \\
\text { Guidelines, 2nd Edition }\end{array}$ & EVM \\
\hline 12 & $\begin{array}{l}\text { Project Management Institute } \\
\text { (PMI) } \\
\end{array}$ & 2006 & $\begin{array}{l}\text { Practice Standard for Work Breakdown } \\
\text { Structures -Second Edition } \\
\end{array}$ & WBS \\
\hline 13 & $\begin{array}{l}\text { Project Management Institute } \\
\text { (PMI) }\end{array}$ & 2005 & $\begin{array}{c}\text { Practice Standard for Earned Value } \\
\text { Management }\end{array}$ & EVM \\
\hline
\end{tabular}


IMPROVING PERFORMANCE OF CONSTRUCTION PROJECTS IN EGYPT BY INTEGARATING RISK INTO EARNED VALUE MANAGEMENT: ALITURATURE REVIEW

\begin{tabular}{|c|c|c|c|c|}
\hline No & Author/ Applicable agency & Date & Topic & Categories \\
\hline 14 & ANSI/EIA-748- B & 2007 & Earned Value Management Systems (EVMS) & EVM \\
\hline 15 & Burke, R. & 2003 & Planning and Control Techniques.4th Ed. & EVM \\
\hline 16 & $\begin{array}{c}\text { Defense Systems } \\
\text { Management College (DSMC) }\end{array}$ & 2001 & Earned Value Management Textbook & EVM \\
\hline 17 & ANSI/EIA-748 & 1998 & Earned Value Management Systems (EVMS) & EVM \\
\hline 18 & Fleming, Koppelman & 1996 & Earned Value Project Management. 2nd ed & EVM \\
\hline
\end{tabular}

\subsection{The Concept of Earned Value Management}

In the late 1800s, Industrial engineers in the factory shop, considered as the origins of the EVM concept (Anbari, 2003; Kim, 2000: Fleming \& Koppelman,2000), because the concept EV was first introduced to US companies that have contracts with the DOD. Over the years, the method and its variants have been used in various names as EVM, Earned Value Method, Earned Value Analysis (EVA), and Cost/Progress Summary Reports. (Fleming \& Koppelman, 2010, 2003; Kim et al., 2003; Kim, 2000).

In 2000, the Project Management Institute (PMI) issued the "Project Management Knowledge System Guide" (PMBOK), which proposed a more simplified EVM formula and terminology (Anbari, 2003). It also explains the essence of the method so that it can be easily implemented in practice.

Project control includes comparison of plans or baseline with actual project results to identify deviations and take early corrective actions when needed. Earned value management is the most effective tool in project performance evaluation. The EVM is a system technology for integrating and measuring triple constraint time, cost, and scope. (Blanco, 2013; Abba and Niel, 2010; Cioffi, 2006; Fleming \& Koppelman, 2005; Jacob \& Kane, 2004; Henderson, 2004; Lipke, 2004b; Henderson, 2003; Anbari, 2003; Burke, 2003; Jacob, 2003; Kim et al., 2003; Lipke, 2003; McKim et al., 2000; Lipke, 1999). It also helps in understanding how to deal with projects from two perspectives. The first is to identify current performance indicators, and the second is to provide predictions for the future to support the program manager's decisions (Noari S.et al.,2008; DSMC, 2001) as shown in figure (3) depicts this relationship. (The project baseline $=$ Scope Baseline + Schedule Baseline + Cost Baseline) .

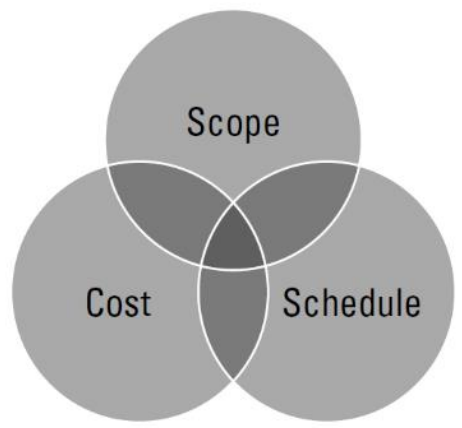

Figure (3): Earned Value Management and Integrating Tool (DSMC, 2001)

Earned value management uses planned value (PV) formerly called Budgeted Cost of Work Scheduled (BCWS); actual cost (AC), called Actual Cost of Work Performed (ACWP); mainly calculated Earned value (EV) was also earlier presented in the form of Budgeted Cost of Work Performed (BCWP). Budget at Completion (BAC) and Estimate at completion (EAC). (PMBok, 2017).

The EVM implement process summarized as "Organize Project- Assign ResponsibilitySchedule -Budget- the Determine Measurement Method- Establish Performance Measurement Baseline (PMB)- Analyze Project Performance - Maintenance PMB " (PMI, 2011). 


\subsubsection{Role of Earned Value Management in Construction Projects}

Several studies have demonstrated the effectiveness of applying EVA such as: (Souza, 2019; Chou, 2010; De Marco, 2009), to meet the project requirements, some have suggested a framework that includes the design and operation of the EVA system to provide evidence of the impacts of the project environment that led to the project's success. (Joby, 2018).

The concept of (EVM) has been studied extensively by scholars (Butler \& Richardson, 2011; Liu \&Tu, 2010; Shepherd, 2010; Song, 2010; Bower \& Finnegan, 2009; Garrett \& Roberts, 2008; Leu \& Lin, 2008; Hillson, 2011, 2004; Besner \& Hobbs, 2006). These scholars attempted to highlight the value of the EVM in costing projects at completion, based on various measurable and estimable costs and the schedule of a project. As an example, (Hillson D., 2004; Infanti G., 2003) presented Earned Value Management as a widely recognized and accepted method of program management, and an effective system for measuring the cost and schedule variances of project implementation. According to limitations of traditional performance appraisal tools, (Hamilton, B.A., 2006) discussed in his paper the EVM method as an effective tool for monitor and control of construction projects.

(PMI, 2005) summarized the role of Earned Value Management as "A very successful reporting and feedback tool that are basic to the achievement of any project. Periodical feedback can empower project managers to early distinguish issues and make changes that can keep a project on time and spending plan, Earned Value Management has turned out to be a standout amongst the best performance measurement and reporting tools for overseeing projects. It empowers managers to close the circle in the plan-do-check-act management cycle"

(Abd El-Latif E., 2014) determines project cost control and its methods, and introduces the EVM method. The research concluded that EVM is the most effective project management tool used to monitor and control project performance, and it can clearly show project performance. ES provides accurate indicators for schedule performance and expresses schedule differences in time units to take corrective action.

(Czemplik, A., 2014) determines the concept of schedule forecast indicators, which will be used as a supplement to EVM to support site management decisions regarding change orders. Research shows that the earned value method can be successfully used not only for cost management of construction projects but also using some other methods for project duration management, even if many change orders should be considered during project execution.

\subsubsection{Extension of Earned Value management " Earned Schedule "}

(Czarnigowska, 2008; Anbari, F. T., 2012) Identified the concept of Earned Schedule (ES) was an extension of the EVM process. In this case the schedule is not specified in terms of money, but in terms of units of duration or time. Earned Schedule replaces Earned Value and Schedule Variance were changed, analysis or management with ES as Earned Schedule Management (ESM) gives a different name, but same concepts. Therefore, ESM rhymes well with the EVM. So Summarized EVM and ESM Elements and their relationships as refer in Figure (4) and equations in the table (5) \& table (6) highlights advantage and disadvantage. Figure (5) clarifies the elements of earned value management and earned schedule, and the contingency reserve as part of the baseline and management reserve. 


\section{IMPROVING PERFORMANCE OF CONSTRUCTION PROJECTS IN EGYPT BY INTEGARATING RISK INTO EARNED VALUE MANAGEMENT: ALITURATURE REVIEW}

Table (5) Comparison between ES and EVM Indicators by (Authors)

\begin{tabular}{|c|c|c|c|c|}
\hline & \multicolumn{2}{|c|}{ Earned Value Managemnt ( EVM ) } & \multicolumn{2}{|c|}{ Earned Schedule ( ES) } \\
\hline & Name & Equation & Name & Equation \\
\hline \multirow{6}{*}{ Statue } & Earned Value ( EV) & $\begin{array}{l}\text { EV or BCWP }=\text { Baseline Cost } * \% \\
\text { Complete Actual }\end{array}$ & Earned Schedule (ES) & $E S=A T-S V(t)$ \\
\hline & Actual Cost ( $\mathrm{AC}$ ) & Costs Spend & Actual Time (AT) & number of periods executed \\
\hline & Schedule Variance (SV) & $S V=E V-P V$ & $\begin{array}{l}\text { Schedule Variance (SV (t)) or Time } \\
\text { Variance (TV) }\end{array}$ & $S V(t)=E S-A T$ \\
\hline & $\begin{array}{l}\text { Schedule performance index } \\
\text { (SPI) }\end{array}$ & $\mathrm{SPI}=\mathrm{EV} / \mathrm{PV}$ & $\begin{array}{l}\text { Schedule Performance Index Time } \\
(\mathrm{SPI}(\mathrm{t})) \text { or the time performance } \\
\text { index (TPI) }\end{array}$ & $\mathrm{SPI}(\mathrm{t})=\mathrm{ES} / \mathrm{AT}$ \\
\hline & \multicolumn{2}{|c|}{ Planned Value ( PV) } & \multicolumn{2}{|c|}{\begin{tabular}{|c|} 
Planned Duration (PD) \\
\end{tabular}} \\
\hline & \multicolumn{2}{|c|}{ Budget at completion (BAC) } & \multicolumn{2}{|c|}{ Schedule at Completion (SAC) } \\
\hline \multirow{6}{*}{$\begin{array}{l}\text { Future } \\
\text { Work }\end{array}$} & \multirow{4}{*}{$\begin{array}{l}\text { estimate at completion (EAC) or } \\
\text { the cost estimate at completion } \\
\text { (CEAC). }\end{array}$} & $E A C=A C+E T C$ & \multirow{4}{*}{$\begin{array}{l}\text { Estimate at Complete Time (EAC (t)) } \\
\text { or time estimate at completion } \\
\text { (TEAC) }\end{array}$} & \multirow{4}{*}{$E A C(t)=P D / S P I(t)$} \\
\hline & & $\mathrm{EAC}=\mathrm{BAC} / \mathrm{CPI}$ & & \\
\hline & & $E A C=A C+B A C-E V$ & & \\
\hline & & $E A C=A C+[(B A C-E V) /(C P I \times S P I)]$ & & \\
\hline & \multirow{2}{*}{ estimate to complete (ETC). } & $\mathrm{ETC}=\left(\mathrm{BAC} \_\mathrm{EV}\right) / \mathrm{CPI}$ & \multirow{2}{*}{$\begin{array}{l}\text { Estimate To Complete (Time) (ETC(t)) } \\
\text { or time estimate to complete (TETC). }\end{array}$} & \multirow{2}{*}{$E T C=E A C(t)-A T$} \\
\hline & & $E T C=E A C-A C$ & & \\
\hline \multirow{3}{*}{ Prediction } & $\begin{array}{l}\text { The cost Variance at Completion } \\
\text { (VAC) }\end{array}$ & $V A C=B A C / E A C$ & $\begin{array}{l}\text { Variance at Completion (VAC(t)) or } \\
\text { The Time Variance at Completion }\end{array}$ & $\operatorname{VAC}(t)=S A C-E A C(t)$ \\
\hline & \multirow[t]{2}{*}{$\begin{array}{l}\text { To complete performance index } \\
\text { (TCPI) }\end{array}$} & $\mathrm{TCPI}(\mathrm{EAC})=(\mathrm{BAC}-\mathrm{EV}) /(\mathrm{EAC}-\mathrm{AC}$ & \multirow[t]{2}{*}{$\begin{array}{l}\text { To Complete Schedule } \\
\text { Performance Index TSPI }\end{array}$} & $\begin{array}{l}\text {TSSPI }=(P D-E S) /(P D-A T) \\
T S P I=(P D-E S) /(E D-A T)\end{array}$ \\
\hline & & $T C P I(B A C)=(B A C-E V) /(B A C-A C)$ & & $E D=$ Estimated Duration \\
\hline
\end{tabular}

\section{Table (6) advantage and disadvantage of EVM and ES by (Authors)}

\begin{tabular}{|c|c|c|c|c|}
\hline \multirow{3}{*}{ Description } & \multicolumn{2}{|c|}{ Earned Value management } & \multicolumn{2}{|c|}{ Earned Schedule } \\
\hline & \multicolumn{2}{|c|}{ Cost and Schedule Indicators } & \multicolumn{2}{|c|}{ Extension for Schedule Indicators } \\
\hline & Disadvantage & advantage & advantage & Disadvantage \\
\hline $\begin{array}{c}\text { Variances } \\
\text { Analysis }\end{array}$ & $\begin{array}{l}\text { It is time-consuming and requires } \\
\text { effort to measure and analyze } \\
\text { performance. Schedule indicators } \\
\text { are unreliable: they express SV in } \\
\text { money units - not time. }\end{array}$ & $\begin{array}{l}\text { Shows the current } \\
\text { situation based on cost } \\
\text { and schedule. }\end{array}$ & $\begin{array}{l}\text { Solve the problems of the } \\
\text { schedule variance by measuring it } \\
\text { in time units. }\end{array}$ & \multirow{2}{*}{$\begin{array}{l}\mathrm{PV}, \mathrm{EV} \text {, and AT are } \\
\text { required to perform } \\
\text { calculations, so it is } \\
\text { very time-consuming } \\
\text { and requires effort to } \\
\text { measure and analyze } \\
\text { performance. }\end{array}$} \\
\hline Forecasting & $\begin{array}{l}\text { The EVM was not used to } \\
\text { estimate the time to completion } \\
\text { or predict an end date. }\end{array}$ & $\begin{array}{l}\text { It enables predictions of } \\
\text { cost at completion date. }\end{array}$ & $\begin{array}{l}\text { It enables predictions of time at } \\
\text { completion. }\end{array}$ & \\
\hline Efficiency & $\begin{array}{l}\text { Past performance is not an } \\
\text { indicator or a guarantee of future } \\
\text { results }\end{array}$ & $\begin{array}{l}\text { Provides indicators that } \\
\text { identify the area of poor } \\
\text { performance and inquire } \\
\text { about corrective actions. }\end{array}$ & $\begin{array}{l}\text { Connects the EVM to the project } \\
\text { schedule.ES can be applied to any } \\
\text { level of the WBS, to include task } \\
\text { grouping as Critical Path. }\end{array}$ & $\begin{array}{l}\text { Past performance is } \\
\text { not an indicator or a } \\
\text { guarantee of future } \\
\text { results }\end{array}$ \\
\hline $\begin{array}{l}\text { Estimating } \\
\text { Accuracy }\end{array}$ & $\begin{array}{l}\text { It does not take into account risks } \\
\text { and uncertainties. }\end{array}$ & $\begin{array}{l}\text { Provide feedback of the } \\
\text { actual performance } \\
\text { against the baseline } \\
\text { estimates. }\end{array}$ & $\begin{array}{l}\text { Accurate indicator for schedule } \\
\text { performance. }\end{array}$ & \multirow[t]{3}{*}{$\begin{array}{l}\text { It does not take into } \\
\text { account risks and } \\
\text { uncertainties. }\end{array}$} \\
\hline \multirow{2}{*}{ Decisions } & \multirow{2}{*}{$\begin{array}{l}\text { It requires a compatible cost } \\
\text { tracking system, and it will never } \\
\text { be } 100 \% \text { accurate. So sometimes } \\
\text { the decision will go wrong. }\end{array}$} & \multicolumn{2}{|c|}{$\begin{array}{l}\text { Provides triggers for escalating problems and helps in taking } \\
\text { sudden decisions. }\end{array}$} & \\
\hline & & \multicolumn{2}{|c|}{ Improves decision making to take corrective action. } & \\
\hline \multirow{3}{*}{$\begin{array}{l}\text { Common } \\
\text { weakness for } \\
\text { each method }\end{array}$} & \multicolumn{4}{|c|}{ Lack of a clear link between EVM indicators and possible management action. } \\
\hline & \multicolumn{4}{|c|}{$\begin{array}{l}\text { In most cases there is no tracking of risk management within EVM. Therefore, the actual work completed may not be } \\
\text { accurate. }\end{array}$} \\
\hline & \multicolumn{4}{|c|}{ Costly and Time Consuming Implementation } \\
\hline
\end{tabular}


IMPROVING PERFORMANCE OF CONSTRUCTION PROJECTS IN EGYPT BY INTEGARATING RISK INTO EARNED VALUE MANAGEMENT: ALITURATURE REVIEW

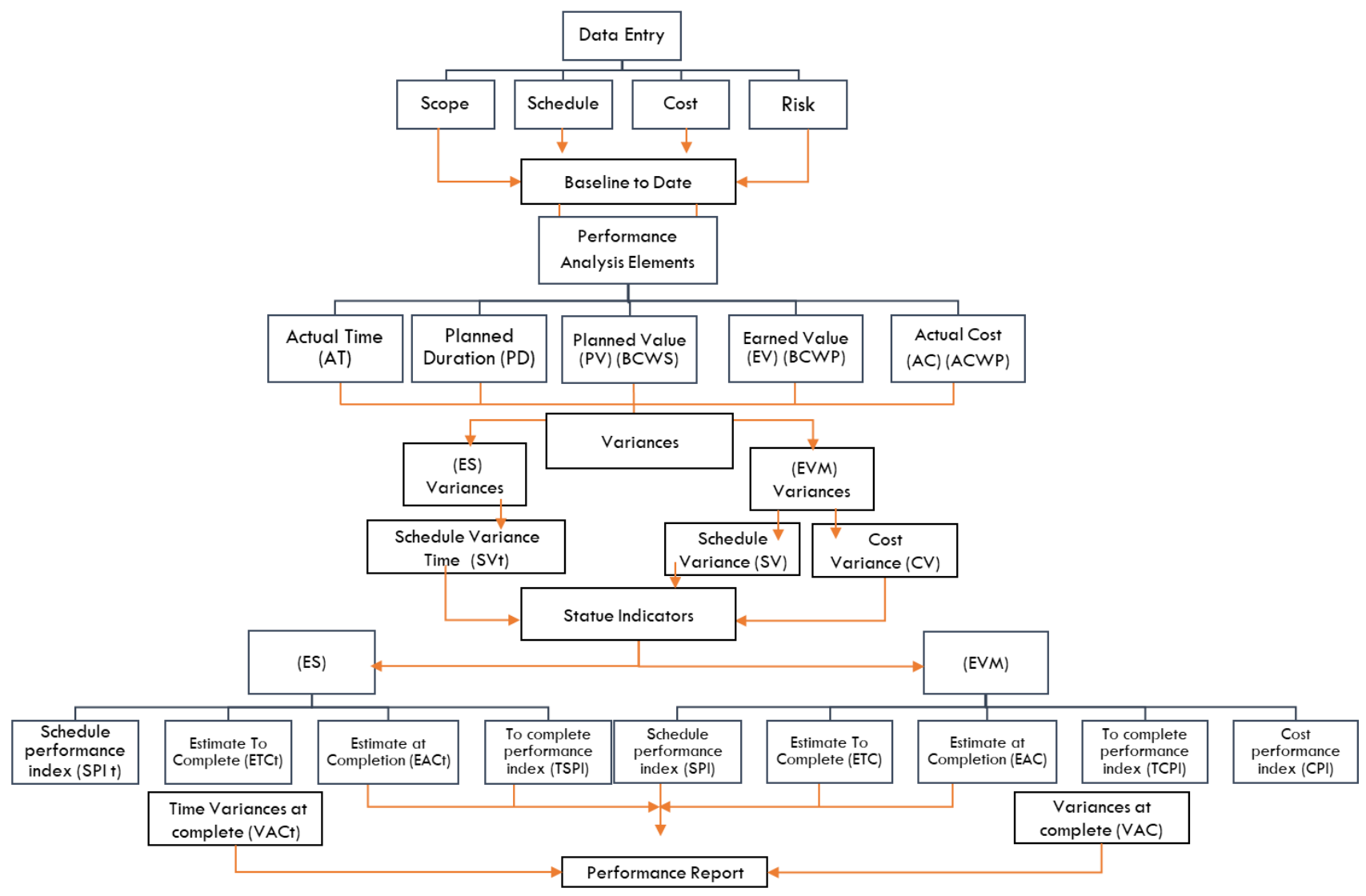

Figure (4) Components of Earned Value Management and Components of Earned Schedule by (Authors)

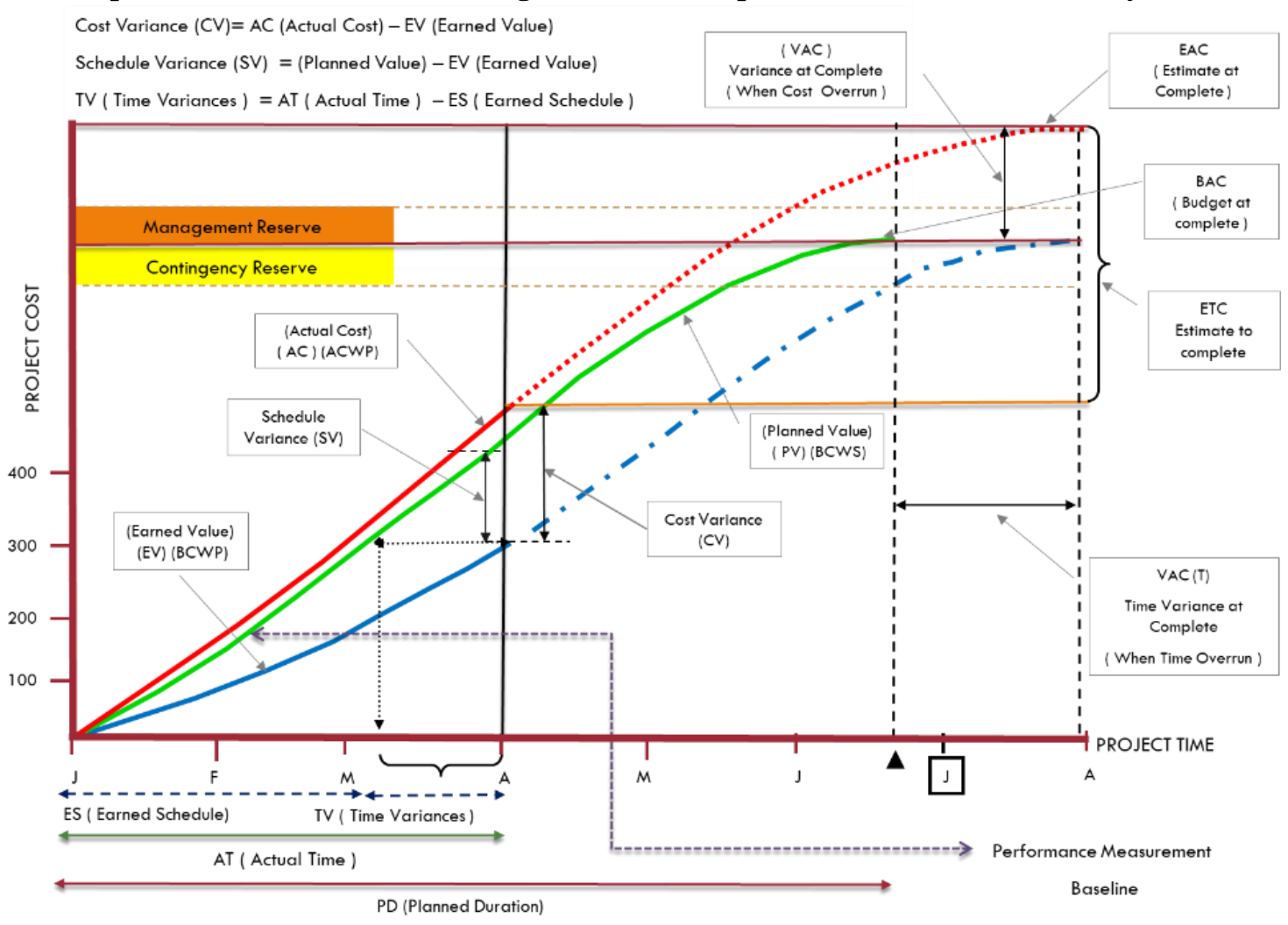

Figure (5): The Component of (EVM - ES), Relation Between (Contingency - Management) \& baseline. Source: Author, updated after (Sheives T., 2011). 


\subsection{The Concept of Risk Management}

Project risk management defined as: " processes related to risk management planning, identification, analysis, response, and monitoring and control" also pointed out: "The goal of project risk management is to increase the probability and impact of positive events, and reduce the probability and impact of negative events in the project"(PMI, 2009; 2008).

\subsubsection{The Role of Risk Management in Construction Projects}

Uncertainties in the construction projects in terms of time, cost, and quality can be managed by utilizing the risk management concept in the project life cycle. Construction project managers can minimize risk factors by prioritizing risk factors. (Gohar, A.S et al.,2012).

Project risk management is one of the foundations of successful project management. It should be applied to all projects and included in the project plans and operating documents. (PMI, 2009). The RM is a useful tool that can help increase the level of project control, and solve problems in the project development process.

Risk management is an important field in the construction industry, and due to large-scale latest research, it has become increasingly important internationally. However, this relatively new field requires more attention to bring some benefits. Construction projects face many risks, which have a negative impact on the project target, such as time, cost, and quality (Iqbal S., 2015).

\subsubsection{Risk Contingencies}

The main risk contingencies discuses in this paper Management Reserve, Contingency Reserve (Cost) (Pmbok, 2017; Tereso, A. et al., 2018; England, K. \& Moreci, J., 2012; PMI, 2011), and Schedule Reserve (Houghton, F. K, 2001) so as shown in table (7) clarifies the concept of each.

Table (7) Risk Reserves Concepts (MR-CR-SR) by (Author)

\begin{tabular}{|c|c|c|c|}
\hline \multirow{3}{*}{ Descriptions } & \multicolumn{3}{|c|}{ Risk Reserves } \\
\hline & \multicolumn{2}{|r|}{ Cost } & Time \\
\hline & Management reserve & Contingency reserve & Schedule reserve \\
\hline Definition & used for unidentified risks. & used to manage identified risks & \multirow{3}{*}{$\begin{array}{l}\text { The amount of time (buffer) } \\
\text { included in the project or planned } \\
\text { schedule to mitigate the impact of } \\
\text { risks or uncertainties that } \\
\text { determined or associated with } \\
\text { specific elements of the project }\end{array}$} \\
\hline baseline & $\begin{array}{l}\text { not including in baseline } \\
\text { cost estimation }\end{array}$ & $\begin{array}{l}\text { including in baseline cost } \\
\text { estimation. }\end{array}$ & \\
\hline responsibility & $\begin{array}{l}\text { they need management's } \\
\text { permission. }\end{array}$ & $\begin{array}{l}\text { The project manager has } \\
\text { authority over the CR. }\end{array}$ & \\
\hline \multirow[b]{2}{*}{$\begin{array}{l}\text { Techniques } \\
\text { for } \\
\text { estimating }\end{array}$} & $\begin{array}{l}\text { a percentage of the cost or } \\
\text { duration of the project. }\end{array}$ & an estimated figure & $\begin{array}{l}\text { Maybe amount in critical path } \\
\text { chain or just percentage from total }\end{array}$ \\
\hline & $\begin{array}{l}\text { It may be } 5 \% \text { of the total } \\
\text { project cost, or it may be as } \\
\text { high as } 10 \% . \text { MR is usually } \\
\text { estimated based on the } \\
\text { uncertainty of the project. }\end{array}$ & \begin{tabular}{|l|} 
There are various techniques, \\
as follows: \\
Percentage of the Project's \\
Cost \\
Expected Monetary Value \\
Decision Tree Analysis \\
Monte Carlo Simulation - PERT
\end{tabular} & $\begin{array}{l}\text { There are various techniques, as } \\
\text { follows: } \\
\text { PERT } \\
\text { Monte Carlo Simulation } \\
\end{array}$ \\
\hline
\end{tabular}

Project RM adds the view of project risk to the output of other processes and increases its value by considering risk. For example, risk management provides a basis for estimating costs and time contingency reserves to include risk response actions to a required level of confidence to achieve project goals (PMI, 2009).

(Sheives T., 2011) demonstrated a simplified method of integrating (RM) into (EVM) through the use of contingency reserves, where used risk work packages, budget, schedule values from the planning process, the paper highlights the importance of estimating risk (uncertainty and probabilistic risk events) using Monte Carlo Simulation with EVM indicators.

(Oritiz I., 2018) explained the gaps in the literature on how general contractors manage threats and opportunities in construction projects and discussed two case studies from large 
Spanish construction companies, and then introduces how to determine how contractors manage time and cost contingencies, the study concluded that managers can not only use time and cost contingencies to manage threats, but also as tools for managing opportunities.

(Houghton, F. K, 2001) The focus on the use of schedule risk assessment to establish contingencies and the need for schedule contingency. Used Monte Carlo simulation to determine the contingency of critical path tasks based on risk, and perform risk-based allocation of available float to non-critical tasks. That provides a way for project managers to assess the progress of project tasks.

\subsection{Earned Value Management and Risk Management Software}

(Subramanian T. et al., 2014) highlighted the main parameters involved in the earned value analysis calculations of construction projects. Compared the EVM parameters when using different software as MS Project 2007, Primavera P6, and the developed software. Therefore, it can be concluded software is used in various projects to perform earned value analysis calculations. Although (EVA) more easily related to the monitoring and evaluation of project costs within the organization, the results showed a strong relationship between each software. The final result can provide more than $99.5 \%$ accuracy. A new element Schedule variance for time (SV t) was determined and incorporated into the developed software, which is not in MS Project 2007 and P6. The final result can provide approximately 100\% accuracy.

(Nalawade S., etal ,2019) discussed main parameter involve in calculation of Earn value analysis. For earn value analysis various software are developed like Visual studio 2008, SQL server 2005, MS project 2007 and primavera p6. Deltek Cobra Considered as a Cost management tool, Cost Risk contingency (MS Excel, @Risk \& Predict!), Schedule Contingency Reserve (MS Project, Primavera, Predict!) (Jonas, V. 2013).

\subsection{Integrating Risk into Earned Value Management}

According to (Georgieva S B.,2014; APM, 2008; Hillson,2004), (EVM) and (RM) both aim to measure project performance by providing data for decision-making and taking actions. So two methods can be integrated to provide strong insights into factors affecting project performance and gaining maximum benefits for projects and organizations.

(Nouban F. et al., 2020) Studies have shown that to achieve project success and improve decision-making, EVM should be applied in the simplest way taking into consideration some factors such as the risk.

(APM, 2008) presented process for integration, so as practical research (Ibrahim M., 2018; Mikawi M. et al., 2017) demonstrated how to use the methodology for implementation of integration between (RM) and (EVM) throughout the different stages of the projects and results proved an integration method is an important tool to monitoring and controlling the project.

$(\mathrm{EVM})$ and $(\mathrm{RM})$ are complementary processes. Both are key aspects of the entire project management discipline (APM, 2008B). Risk management is related to what happens in the future; earned value management involves using what has happened to predict and control the future. Integrating these two processes can produce a useful framework (APM, 2008).

(APM, 2008B) suggested to list the areas where risk management and earned value management can be usefully integrated.

A. Estimating the project activities (cost and schedule): contingency activities

B. Establish a management reserve budget.

C. Create and control the Cost and Time for the RM process

D. Schedule: Incorporating (RM) activities in the baseline schedule. Establishing dependencies. Determining the risk inherent within the schedule by using statistical risk network analysis. Risk modeling to optimize project schedules.

E. Including RM activities in project performance analysis: Including resource, cost, and the schedule for risk management activities in overall project earned value. Use the EV to determine the performance of risk management activities. 
F. Development of forecasts: An estimate at completion (cost). Schedule forecast (time). Modeling with the risk network.

G. Change management: Incorporation of MR budget for contingency activities.

Earned value management and project risk management are considered separately in project management. According to PMBOK®, EVM is part of the project time and cost management knowledge areas, while project risk management is a different field of knowledge and has no obvious relationship to the previous knowledge field, although the foundation of (EVM) affected by risk management, where is the purpose to clarify the mechanism of this relation. (Tereso A. et al., 2018) This study explores the interconnection between these two methods and proposes an integration framework for them. The framework is implemented in Excel, resulting in a set of tools that can be used to monitor and control projects.

(KhodaBandeh Lou et al., 2016; Hillson, D., 2004) explained that both EVM and RM technologies support the decision and should be applied in an integrated throughout the organization. EVM and RM provide powerful insights into the factors affecting project performance. The possibility of developing a combined approach that produces synergistic benefits. Currently, EVM and RM operate as parallel coexisting processes without system integration.

Integrating RM and EVM to predict and estimate the cost and time of project completion is an effective tool for project management and control (KhodaBandeh Lou et al., 2016).

(Pajares and López-Paredes, 2011) introduced two new indicators for integrating EVM and project risk management methods: cost control and schedule control indices. If the project is operating under risk analysis assumptions, these two indices compare EVM measures with the maximum value that the project should exhibit. (Acebes et al.,2013) integrated the dimensions of the project cost and schedule with risk management by proposed a graphical framework for EVM.

(Akhtar T., 2017) This study evaluated the possibility of using EVM and RM in an integrated approach in commercial construction projects in Pakistan. From the literature review, a theoretical framework is drawn in which EVM and RM can be incorporated to enhance project performance. The results support the belief that the incorporation of EVM and RM adds value to the project.

(Shepherd B., 2008) defined several essential concepts related to control accounts, risk management, and earned value management and describes how to combine them to develop an integrated estimate of cost and schedule. The methodology discusses risk-earned value management-control accounts-work packages, and how to put them together. The conclusion by applying the CPI and SPI to the remaining cost and time before running the Monte Carlo simulation, an integrated view of the impact of risk and EVM on program cost and schedule can be obtained.

(Bonato F.al et al., 2019) this paper integrated and applied earned value management with a Monte Carlo simulation to predict the final cost of three specific engineering projects, and evaluate model performance and projects in each case study. The results of three project simulations assessed qualitatively and comparatively, indicating that the integration between tools provides useful forecasts for project management.

The integration between two methods EVM and RM has been studied by scholars (Acebes et al., 2012; Lipke, 2011; Pajares and Lopez, 2011; Hillson, 2004; APM, 2008; Risk Decisions LTD and BMT Sigma LTD, 2003). Those researchers and organizations did highlight and stress the importance and efficacy of integration between both EVM and RM. In the last decade, research on the integration of EVM and RM has involved the use of EVM methods, which can then be used with RM strategies to determine how these calculations were affected by different risks. Applying EVM results to RM strategies is only a potential way to integrate EVM and RM (PMI, 2011a; Shepherd, 2010).

According to (APM,2008; Shepherd B., 2008; Hillson D., 2004; Georgieva, S.B.,2014) summarized in table (8) below how EVM and Risk complete each other if integrated. 
IMPROVING PERFORMANCE OF CONSTRUCTION PROJECTS IN EGYPT BY INTEGARATING RISK INTO EARNED VALUE MANAGEMENT: ALITURATURE REVIEW

Table (8) Discussed the weakness and similarities of each method (EVM \& RM) by (Authors)

\begin{tabular}{|c|c|c|}
\hline Description & Earned Value Management & Risk Management \\
\hline concept & $\begin{array}{l}\text { EVM establishes the status of project } \\
\text { performance and presents that information to } \\
\text { understand future trends and the allocation of } \\
\text { resources required to successfully achieve } \\
\text { these goals. }\end{array}$ & $\begin{array}{l}\text { RM looks at the unknown future to identify } \\
\text { risks (threats and opportunities) and } \\
\text { recommends early actions to limit the } \\
\text { impact and possibility of threats or to } \\
\text { maximize opportunities. }\end{array}$ \\
\hline \multirow[t]{2}{*}{ Advantage } & $\begin{array}{l}\text { Examines what happened to the project and } \\
\text { uses quantitative indicators to evaluate the } \\
\text { past performance of the project. }\end{array}$ & $\begin{array}{l}\text { Estimate the level of certainty in the project } \\
\text { baseline to keep project performance and } \\
\text { estimate reserves to mitigate risks. }\end{array}$ \\
\hline & EV focuses on reporting past performance. & RM focuses on responding to future events. \\
\hline weaknesses & $\begin{array}{l}\text { EVM assumption that the future performance } \\
\text { of the project can be predicted based on the } \\
\text { past performance. }\end{array}$ & $\begin{array}{l}\text { RM always seeks future conditions without } \\
\text { considering or analyzing past performance. }\end{array}$ \\
\hline \multirow{3}{*}{ similarities } & \multicolumn{2}{|c|}{$\begin{array}{l}\text { EVM and RM are, in their way, informing project baseline estimates by using both objective } \\
\text { and subjective data. Estimating uncertainty can be reduced by comparison of data outputs } \\
\text { from both disciplines, providing a better understanding of project progress and predicted }\end{array}$} \\
\hline & \multicolumn{2}{|c|}{$\begin{array}{l}\text { EVM and RM are directed towards measure project performance by providing data used to } \\
\text { make decisions and take actions. }\end{array}$} \\
\hline & \multicolumn{2}{|l|}{ EVM and RM move from analysis to management. } \\
\hline
\end{tabular}

\section{Findings}

According to the chosen previously researches studied (75), different researches including papers and thesis published in many countries like Egypt, the United States of America, the United Kingdom, Turkey, Malaysia, India, Spain, and Portugal, Literature sources can be categorized as mentioned in Tables $(1,2,3)$ published during the last decade. (Earned Value Management -Risk Management -Risk Reserves -Integration of EVM and RM- EVM \& RM Software). As a result of these studied sources, so summarized the topic as firstly an identify the impact of integrating risk into EVM on the project performance and secondly identify the guidelines for integrating applications.

\subsection{Identify the Impact of Integrating Risk into EVM on the Project Performance}

- Table (8) show that each process has weaknesses and similarities, so EVM and RM can combine their respective advantages. Through using the data from the EVM, we can provide more data about RM techniques.

- The fundamentals of EVM are fully affected by risk management and risk analysis, which makes it necessary to clarify each risk component in the EVM methodology.

- The previous studies indicated that, if used EVM and RM together, they provide a potent framework for managing change on a project based on a realistic assessment of past performance and future uncertainty, and it can implement through practical and wise solutions that help decision making.

- The paper summarizes (EV- AC-PV- ES- PD) elements in the graph as mentioned in the figure (3), which clarified the importance of estimating contingency reserves as part of baseline creation to get accurate results when applying the EVM equation.

\subsection{Identify the Guidelines for Integration Application.}

- The ES should implement with the EVM in project control. Refer to Table (6) and Figure (4).

- According to the disadvantages of using the EVM mentioned in table (6): In order to avoid the time required to collect all relevant data related to actual cost and time, and the high costs of the EVM system, it requires putting in place a system with new software to support the EVM process and be able to generate the data and timely reports, where costs will reduce due to technological innovation and faster information transfer as well as new software. 
- This paper emphasizes the importance of integrating EVM into risk in the excavation phase, and there are situations where risk should be integrating:

- Estimate cost contingency reserve.

- Add contingency reserve in work package as part of baseline cost to establish cost baseline.

- Estimate management reverses and adds it to the total project cost.

- Estimate schedule reserve.

- Add the schedule reserve/buffer to the total time or critical paths to establish the schedule baseline.

- Forecast EAC for the actual cost baseline "predict the future."

- Use EVM equations and thresholds to understand the risk situation and its effectiveness on the project performance.

If risk reserves are included in the estimation of the project "cost/time" baselines, it can give accurate results when comparing the estimated value to actual values which affect the corrective action.

\section{Conclusion}

The paper managed to identify and highlight the impact of integration-earned value management and risk through a literature review that recalls the need for an effective tool to help project managers to monitor and control the project, therefore this paper recommends applying the integration of Earned Value Management into Risk from cost and time perspective for better efficiency and performance of construction projects with using of more accurate software like primavera software. This paper serves as the foundation in the master thesis structure, which provides a promising direction to complete the research, and find practical solutions to the research field.

\section{REFERENCES:}

1. Anbari, F.T. (2003). Earned Value Project Management Method and Extensions. Project Management Journal 34(4), 12-23.

2. Anbari, F. T. (2012). The earned schedule. Paper presented at PMI® Research and Education Conference, Limerick, Munster, Ireland. Newtown Square, PA: Project Management Institute.

3. Acebes et al. (2012). Beyond Earned Value Management: A Graphical Framework for Integrated Cost, Schedule and Risk Monitoring. 26th IPMA World Congress, Crete, Greece.

4. Acebes F, Pajares J, Galán JP, López-Paredes A. (2013). Beyond Earned Value Management: A Graphical Framework for Integrated Cost, Schedule and Risk Monitoring. Procedia - Social and Behavioral Sciences, 74: 181-189.

5. Abd El-Latif, E. (2014). Using the Earned Value Management System to Measure and Improve Construction Project Control. Master Thesis, Alexandria University, Structural Department.

6. Association for Project Management (APM) (2008). Interfacing Risk and Earned Value Management. High Wycombe, Bucks, UK: APM Publishing.

7. Association for Project Management (APM) (2008B), Earned Value Management: APM Guidelines, 2nd Edition, Earned Value Management SIG (Specific Interest Group).

8. Akhtar T. (2017). An Investigation into Performance Appraisement of Commercial Buildings Construction Projects in Pakistan by Integrating Earned Value Management and Risk Management. Centre for Advanced Studies in Engineering, Islamabad, Pakistan.

9. Aziz, R.F. (2013). Ranking of delay factors in construction projects after the Egyptian revolution. Alexandria Engineering Journal, Vol. 52 No. 3, pp. 387-406.

10. Assaf, S. A., \& Al-Hejji, S. (2006). Causes of Delay in Large Construction Projects. International Journal of Project Management, 349-357.

11. Abba, W., Niel, F.A., (2010). Integrating technical performance measurement with earned value management. Meas. News 4, 6-8.

12. Butler, C. W. \& Richardson, G. L. (2011). A variable time project planning and control model. Journal of Management Policy and Practice. 
13. Besner, C., \& Hobbs, B. (2006). The perceived value and potential contribution of project management practices to project success. Project Management Journal, 37(13), 37-48.

Retrieved from http://www.csun.edu/ aa2035/CourseBase/ProjectMgt/ProjectMgt2010/PMfromJump1/D rSwafford/PMValueofProjectPractices.pdf.

14. Bower, D. C., \& Finnegan, A. D. (2009). New approaches in project performance evaluation techniques. International Journal of Managing Projects in Business, 2(3), 435 444. doi: 10.1108/17538370910971072.

15. Bonato, F. K., Albuquerque, A. A., \& Paixão M. A. S. (2019) .An application of Earned Value Management (EVM) with Monte Carlo simulation in engineering project management. Gestão \& Produção, 26(3), e4641. https://doi.org/10.1590/0104-530X46412019.

16. Blanco, V.D., (2013). Earned value management: a predictive analysis tool. Nav. Supply Corps Newsl. 66 (2), 24-27.

17. Burke, R., (2003). Project Management. John Wiley \& Sons, Planning and Control Techniques. 4th Edition, London etc.

18. Czarnigowska Agata. (2008). Earned value method as a tool for project control. Institute of Construction, Faculty of Civil and Sanitary Engineering, Lublin University of Technology.

19. Czemplik, A. (2014). Application of Earned Value Method to Progress Control of Construction projects. Theoretical Foundation of Civil Engineering, Procedia Engineering, Volume 91, 2014, Pages 424-428.

20. Cioffi, D.F. , (2006). Designing project management: a scientific notation and an improved formalism for earned value calculations. Int. J. Proj. Manag. 24 (2), 136-144.

21. Chou, J.-Sh. Et al. (2010). Visualized EVM system for assessing project performance ". Automation in Construction.19(5), 596-607.

22. Defense Systems Management College (DSMC), (2001). Earned Value Management Textbook. Fort Belvoir, VA: Defense Systems Management College Press.

23. De Marco, A., Briccarello, D. \& Rafele, C. (2009). Cost and schedule monitoring of industrial building projects: Case study. Journal of Construction Engineering and Management, 135(9), 853-862.

24. England, K. \& Moreci, J. (2012). Contingency-are you covered? Paper presented at PMI® Global Congress 2012-North America, Vancouver, British Columbia, Canada. Newtown Square, PA: Project Management Institute.

25. Fleming, Quentin W., and Joel M. Koppelman. (1994). The Essence and Evolution of Earned Value. Cost Engineering. Nov. 1994: 21-27.

26. Fleming, Q., Koppelman, J. (2000). Earned Value Project Management. Second Edition, Newtown Square, Project Management Institute.

27. Fleming, Q., Koppelman, J.(2003). What's your project's real price tag? Harvard Business Review, September 2003.

28. Fleming, Q., Koppelman, J. (2010). Earned value project management. Fourth Edition, Newtown Square, Project Management Institute.

29. Georgieva, S.B. (2014). A Method for Choosing a Project's Planned Value Curve by Integrating Earned Value and Risk Management. Economic Alternatives, 5(2): 59-76.

30. Gohar,A.S., Khanzadi,M. \&Farmani ,M.(2012). Identifying and Evaluating Risks of Construction Projects in Fuzzy Environment: A Case Study in Iranian Construction Industry", Indian Journal of Science and Technology, 5(11): 131-152.

31. Garrett, G., \& Roberts, D. (2008). Earned Value: Government and industry challenges. Contact Management, 48(11), 24-30. Retrieved from http://www.ncmahq.org/files/articles/cm1108\%20-\%20pages\%2024-30.pdf.

32. Hamilton, B.A. (2006). Earned Value Management Tutorial Module1: Introduction to Earned Value Management. United States of America Department of Energy, http://www.science.doe.gov/opa/pdf/FinalModule1.ppt.

33. Henderson, K., (2004). Further developments in earned schedule. Meas. News 15-22.

34. Henderson, K. (2003). Earned Schedule: A Breakthrough Extension to Earned Value Theory? A Retrospective Analysis of Real Project Data. The Measurable News, 6. 
35. Hilson D. (2004). Earned Value Management and Risk Management: A Practical Synergy. Global Congress Proceeding, PMI, Anaheim, California, USA.

36. Hillson D (2011). Combining Earned Value and Risk Management: A practical synergy. EVIAP Project control and EVM conference. Lisbon, Portugal. Retrieved from http://www.ukessays.com/essays/projectmanagement/the-integrating-earnedvaluemanagement.php Retrieved from UK ESSAYS: http://www.ukessays.com.

37. Houghton, F. K., (2001). LANL's development of schedule contingency based on probabilistic risk results. Paper presented at Project Management Institute.

38. Ibrahim, M. (2018). The Integration between Earned Value Management and Risk Management in Construction Projects. Master Thesis, Ain Shams University, Structural Department.

39. Iqbal S. et al. (2015). Risk management in construction projects. Technological and Economic Development of Economy, 21:1, 65-78, DOI: 10.3846/20294913.2014.994582.

40. Infanti G. (2003). Integrating Risk Management with Earned Value Management. National Defense Industrial Association Program Management Systems Committee (NDIAPMSC).

41. Jacob, D.S. (2003). Forecasting project schedule completion with earned value metrics. Meas. News 7-9.

42. Jacob, D.S., Kane, M. (2004). Forecasting schedule completion using earned value metrics. revisited. Meas. News 11-17.

43. Joby, D. B. (2018). Conditions of success for earned value analysis in projects. International Journal of Project Management, 36(3), 397-582.

44. Jonas, V. \& Bone, L. (2012). Interfacing earned value and risk management. Paper presented at PMI® Global Congress 2012-EMEA, Marsailles, France. Newtown Square, PA: Project Management Institute.

45. Jonas, V. (2013). Understanding risk contingency and MR - how risk tools can help. Risk Decisions Group, https://www.slideshare.net/assocpm/5-calculating-contingency-for-mrval-jonas .

46. KhodaBandeh Lou , et al. (2016). Integratıng Earned Value Management with Risk Management to Control the Time-Cost of The Project. Semantic Scholar: https://pdfs.semanticscholar.org/dcc8/e98602e0f968a70 0e4a5a834075636e82abb. Retrieved from pdf.

47. Kim, E. (2000). A study on the effective implementation of earned value management methodology. (Doctoral dissertation). George Washington University.

48. Kim, E., Wells Jr., W., \& Duffey, M. (2003). "A model for effective implementation of Earned Value Management methodology", International Journal of Project Management, 375-382.

49. Khodeir L. \& Mohamed A. (2015). Identifying the latest risk probabilities affecting construction projects in Egypt according to political and economic variables. From January 2011 to January 2013, HBRC Journal, 11:1, 129-135, DOI:10.1016/j.hbrcj.2014.03.007.

50. Lipke, W.H., (1999). Applying management reserve to software project management. J. Def. Softw. Eng. 17-21.

51. Lipke, W. (2003). Schedule is different. Meas. News 3, 31-34.

52. Lipke, W. (2004b). The probability of success. J. Qual. Assur. Inst. 14-21.

53. Lipke, W. (2011) .Earned Schedule Application to Small Projects. PM world today Featured Paper.

54. Leu S. and Lin Y. (2008). Project performance evaluation based on statistical technique control techniques. Journal of Construction Engineering \& Management, 134(10), 813819. doi:10.1061/ (ASCE) 0733-9364(2008)134:10(813).

55. Liu, S., and Tu, J. (2010). Project management plan: Increasing enrolment rate for the Transworld Institute of Technology. International Journal of Business and Management.

56. Marzouk, M. M., \& El-Rasas, T. I. (2014). Analyzing Delay Causes in Egyptian Construction Projects. Journal of Advanced Research, 5, 49-55.

57. Mikawi M., Khalil A., Asaad M. (2017). Integrated Earned Value Management and Risk Management Approach in Construction Projects.Volume-7, Issue-4, July-August 2017 International Journal of Engineering and Management, P.g: 286-291. 
58. M. E. Abd El-Razek; H. A. Bassioni; A. M. Mobarak (2008). Causes of Delay in Building Construction Projects in Egypt, Journal of Construction Engineering and Management ASCE/ November 2008/831.

59. McKim, R., Hegazy, T., Attalla, M., (2000). Project performance control in reconstruction projects. J. Constr. Eng. Manag. 126 (2), 137-141.

60. Nawar, S. (2017). Owner Time and Cost Contingency Estimation for Building Construction Projects in Egypt. Master thesis, School of Sciences and Engineering, The American University in Cairo, Egypt.

61. Nalawade S., Ghode O., Vaidya P. (2019). Earn value analysis of construction project using primavera p6. Cikitusi Journal for Multidisciplinary Research.

62. Noari S., Pour M., and Zareei A. (2008). Applying Fuzzy Control Chart in Earned Analysis: A New Application. World Applied Sciences Journal 3, IDOSI Publications.

63. Ortiz, J. I., Pellicer, E., \& Molenaar, K. R. (2018). Management of time and cost contingencies in construction projects: a contractor perspective. Journal of Civil Engineering and Management, 24(3), 254-264. https://doi.org/10.3846/jcem.2018.1643.

64. Pajares J, López-Paredes A. (2011). An extension of the EVM analysis for project monitoring: The Cost Control Index and The Schedule Control Index. International Journal of Project Management. 29: 615-621.

65. Project Management Institute (PMI) (2005). Practice standard for Earned Value Management. Project Management Institute, Inc.

66. Project Management Institute (PMI) (2008). A guide to the Project Management Body of Knowledge (PMBOK guide) (4th ed.). Project Management Institute.

67. Project Management Institute (PMI) (2009). Practice Standard for Project Risk Management. 14 Campus Blvd., Newtown Square, PA 19073-3299 USA.

68. Project Management Institute (PMI) (2011). Practice Standard for Earned Value Management. Second Edition ,14 Campus Blvd., Newtown Square, PA 19073-3299 USA.

69. Project Management Institute (PMI) (2017). A guide to the Project Management Body of Knowledge (PMBOK guide) (6th ed.). Project Management Institute.

70. Project Management Institute(PMI)(2011a). Practice standard for Earned Value Management, Project Management Institute, Inc.

71. Risk Decisions LTD and BMT Sigma LTD ( 2003 ).Integrating Risk and Earned Value Management White Paper, Retrieved as pdf http://www.microplanning.com.au/wpcontent/uploads/2011/10/57-Risk-and-Earned-Value-Management-whitepaper.pdf.

72. Rosenfeld, Y. (2014). Root-Cause Analysis of Construction Cost Overruns. Journal of Construction Engineering and Management.

73. Sambasivan, M., \& Soon, Y. W. (2007). Causes and effects of delays in Malaysian Construction Industry. International Journal of Project Management, 517-526.

74. Shepherd, B. (2008). Integrating risk and earned value management. Paper presented at PMI® Global Congress 2008-North.

75. Shepherd, B. (2010). Effective earned value management. Paper presented at PMI® Global Congress 2010 - North America, Washington, DC. Newtown Square, PA: Project Management Institute.

76. Sheives, T. (2011). Integration of earned value and risk management using contingency reserves. Paper presented at PMI ${ }^{\circledR}$ Global Congress 2011 - North America, Dallas, TX. Newtown Square, PA: Project Management Institute.

77. Shrivastava, N. K. (2014). A model to develop and use risk contingency reserve. Paper presented at PMI® Global Congress 2014-North America, Phoenix, AZ. Newtown Square, PA: Project Management Institute.

78. Song, L. (2010). Earned Value Management. Global and cross-country perspective. Newtown Square, PA: Project Management Institute.

79. Souza, A. D. (2019). A Systematic Review Based on Earned Value Management and Quality. International conference on information technology, 135-141.

80. Shibnai A. ,Salah K. (2015). Time and Cost Overrun in Construction Projects in Egypt. MSC student Coventry University, UK. 
81. Subramani T., Jabasingh D. S. Stephan, Jayalakshmi J. (2014). Analysis of Cost Controlling in Construction Industries by Earned Value Method Using Primavera. Int. Journal of Engineering Research and Applications, ISSN: 2248-9622, Vol. 4, Issue 6(Version 1), June 2014, pp.145-153.

82. Tereso, A., Ribeiro, P. and Cardoso, M. (2018). An Automated Framework for the Integration between EVM and Risk Management. Journal of Information Systems Eng.

83. Wanjari, S. P., \& Dobariya, G. (2016). Identifying Factors Causing Cost Overrun of the Construction Projects in India. Sadhana, 679-693.

84. Yahia, H., Hosny, H., \& Razik, M. E. (2011). Time Contingency Assessment in Construction Projects. International Journal of Computer Science Issues, 523-531. 